\title{
Secondary Metabolites Production by Actinomycetes and their Antifungal Activity
}

\section{Tirta Kumala Dewi, Dwi Agustiani, and Sarjiya Antonius}

Research Center for Biology, Indonesian Institute of Sciences, Jl. Raya Jakarta Bogor KM 46, Cibinong, Bogor 16911, Indonesia

\section{Abstract}

Wilt desease of banana caused by Fusarium oxysporum f.sp. cubense (FOC) is one of the most destructive deseases of banana in the tropics. Actinomycetes are the most economically and biotechnologically valuable prokaryotes able to produce wide range of bioactive secondary metabolites. The aims of the present study are to isolate and screen the actinomycetes with high potential ability to produce secondary metabolites that have inhibitory activity against plant pathogenic fungi, Fusarium oxysporum f. sp. cubense. Two isolates from Lampung and Cianjur showed activity against fungi. The isolates designed as L.3.1 and CilA5b. The metabolites from potent stain was produced by extraction of culture filtrate with ethyl acetate : methanol $(4: 1)$, it was tested for their antifungal activity by well diffusion method. Evidence for in vitro antibiosis of L.3.1 and CilA5b isolates was demonstrated by the zone of fungal-growth inhibition. Production of secondary metabolites was analysis by thin layer chromatography (TLC)

Corresponding Author: Tirta Kumala Dewi tirta.kdewi@gmail.com Received: 11 February 2017 Accepted: 08 March 2017 Published: 26 March 2017

Publishing services provided by Knowledge $\mathrm{B}$

(c) Tirta Kumala Dewi et al. This article is distributed under the terms of the Creative Commons Attribution License, which permits unrestricted use and redistribution provided that the original author and source are credited.

Selection and Peer-review under the responsibility of the ICBS Conference Committee.

\section{G OPEN ACCESS} and bioautography assays. In this study, the metabolites from L.3.1 and CilA5b have showed good antifungal activity.

Keywords: Actinomycetes; antifungal activity; bioautography; secondary metabolites; thin layer chromatography.

\section{Introduction}

Here fungal phytopathogens are the cause of many plant diseases and much loss of crop yields, especially in subtropical and tropical regions [1]. Wilt desease of banana caused by Fusarium oxysporum f.sp. cubense (FOC) is one of the most destructive deseases of banana in the tropics [2]. Microorganisms are biological control agents have high potential to control plant pathogens and no effect on the environment. There presently exist numerous reports on potential use of biocontrol agents as replacements of agrochemicals [3-5].

Actinomycetes are the most economically and biotechnologically valuable prokaryotes able to produce wide range of bioactive secondary metabolites, such as antibiotics, antitumor agents, immunosuppressive agents and enzymes. These metabolites are known to posses antibacterial, antifungal, neuritogenic, anticancer, antialgal, antimalarial and anti-inflammatory activities [6]. Around 23000 bioactive secondary metabolites produced by microorganisms have been reported and over 10000 of these 
compounds are produced by Actinomycetes, representing $45 \%$ of all bioactive microbial metabolites discovered [7]. Among Actinomycetes, around 7600 compounds are produced by Streptomyces species. Many of these secondary metabolites are potent antibiotics, which has made Streptomyces the primary antibiotic producing organisms exploited by the pharmaceutical industry [8-10]. Most Actinomycetes in soils belong to the genus Streptomyces [11] and $60 \%$ of the sources of most biologically active compounds that have been developed for agricultural use are originated from them [3]. Streptomyces, as the most important genus of Actinomycetes, are the most abundant soil microorganisms under a wide variety of conditions. This genus was confirmed to promising bacteria against several pathogens and is well known for their potential to produce a large number of inhibitory metabolites used in industry and pharmacy $[12,13]$.

Streptomyces are found in plant rhizosphere [3] and attention has been paid to the possibility that they can protect roots by inhibiting the development of potential fungal pathogens. This may be achieved through by the production of enzymes, which degrade the fungal cell wall, or antifungal compounds [14-16].

Secondary metabolism usually occurs at the late growth phase. The temporal nature of secondary metabolism is genetic but expression can be influenced greatly by environmental manipulations. Therefore, secondary metabolism is often brought on by exhaustion of a nutrient, or addition of an inducer and/or by a decrease in growth rate, or by different environmental signals produced by other organisms in soil e.g $\gamma$-butyrolactonens produced by most Streptomyces and by other Actinomycetes [17].

The bioautography is one of the techniques useful in direct tracing out bioactive compounds from extracts on thin layer chromatogram [18]. Antifungal bioautographic assays system have used clasically one-dimensional thin layer chromatography (TLC) to separate the chemical constituent from the extract. Antifungal metabolites can be readily located on the plates by visually observing clear zones where active compound inhibit fungal growth.

Hence, the objectives of this study are to isolate Actinomycetes from soils and screen secondary metabolites that have inhibitory activity against plant pathogenic fungi.

\section{Materials and Methods}

\subsection{Isolation of Actinomycetes}

Soil samples were obtained from the rhizosphere of banana plantation in Lampung and Cianjur, West Java. The five $\mathrm{g}$ of soil were suspended in $45 \mathrm{~mL}$ aquadest in the Erlenmeyer flask. Erlenmeyer flasks were incubated on a rotary shaker [(125 rpm) (1 rpm $=1 / 60 \mathrm{~Hz}$ )] at room temperature for $30 \mathrm{~min}$. Actinomycetes were isolated by spread plate technique following the serial dilution of soil samples. Following incubation at $28^{\circ} \mathrm{C}$ for $4 \mathrm{~d}$, isolated colonies were subcultured on International Streptomyces Project (ISP) agar medium until pure cultures were obtained. 


\subsection{Extraction of secondary metabolites of Actinomycetes}

L.3.1 and CilA5b isolates were inoculated in $2.5 \mathrm{~L}$ of International Streptomyces Project medium, $\mathrm{pH} 7.0$ and incubated at $28^{\circ} \mathrm{C}$ with shaking for $4 \mathrm{~d}$. Each liquid culture was extracted with ethyl acetate : methanol $(4: 1)$. The organic extracts were concentrated by rotary evaporation and dissolved in methanol. The concentrated products were regarded as crude samples and kept at $-20^{\circ} \mathrm{C}$. The antifungal activity of the crude samples was checked.

\subsection{Screening of antifungal activity}

Fusarium oxysporum f. sp. cubense was cultured on potato dextrose agar (PDA), incubated at $28^{\circ} \mathrm{C}$ for $4 \mathrm{~d}$. Mycelia discs of $0.6 \mathrm{~cm}$ diameter of this fungal pathogen was transferred from PDA onto the center of PDA plates. The inhibition of fungal growth was observed by agar well diffusion method. The $100 \mu \mathrm{L}$ of L.3.1 and CilA5b extracts were transferred on the the plate, $3 \mathrm{~cm}$ away from the fungal discs. The plates were incubated at $28^{\circ} \mathrm{C}$ for $4 \mathrm{~d}$. The $100 \mu \mathrm{L}$ of methanol were placed on the plates, $3 \mathrm{~cm}$ away from the fungal discs as a negative control.

\subsection{Thin Layer Chromatography (TLC)}

The $10 \mu \mathrm{L}$ of each extract were blotted on a Silica Gel 60 F264 (Merck) used for TLC. TLC plates were developed with dichloromethane : methanol $(9: 1)$ and the extract spot was allowed to develop of the plates. TLC plates were the removed from the solvent chamber immediately before the solvent reached the top of the plates. Each plates was allowed to develop until the solvent reached $1 \mathrm{~cm}$ from the top and then placed it in an UV viewing cabinet $(254 \mathrm{~nm})$ [18], and buthanol : acetic acid : water $(4: 1: 5)$ described by Hemashenpagam [19] then visualized by UV light. Retention factors (Rf) were calculated.

\subsection{The Bioautography}

Inhibition of fungal growth on chromatographic plates was evaluated by TLC bioautography system. The chromatogram was kept for evaporation of the solvent. Developed chromatogram was placed on sterile potato dextrose agar. Potato dextrose agar with a spore suspension was poured on chromatogram. Zone of inhibition was checked after incubation [20].

\section{Result and Discussion}

Two isolates were selected from the rhizosphere of banana plantation. The isolates designed as L.3.1 and CilA5b. The rhizosphere represents a unique biological niche that supports an abundance of diverse saprophytic microorganisms due to a high input of 


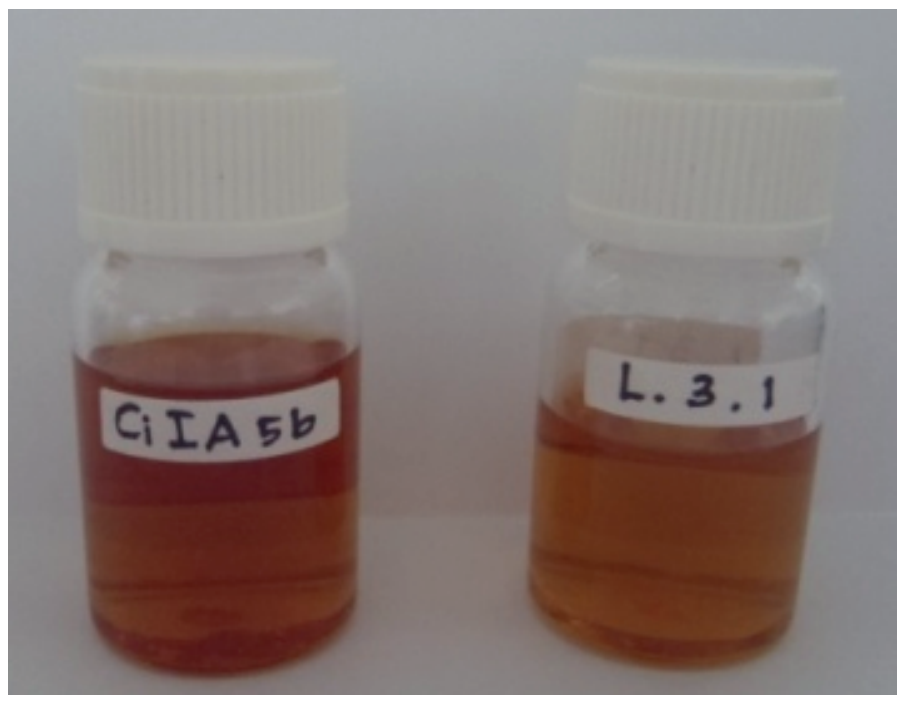

Figure 1: Extract of culture filtrate of L.3.1 and CilA5b.

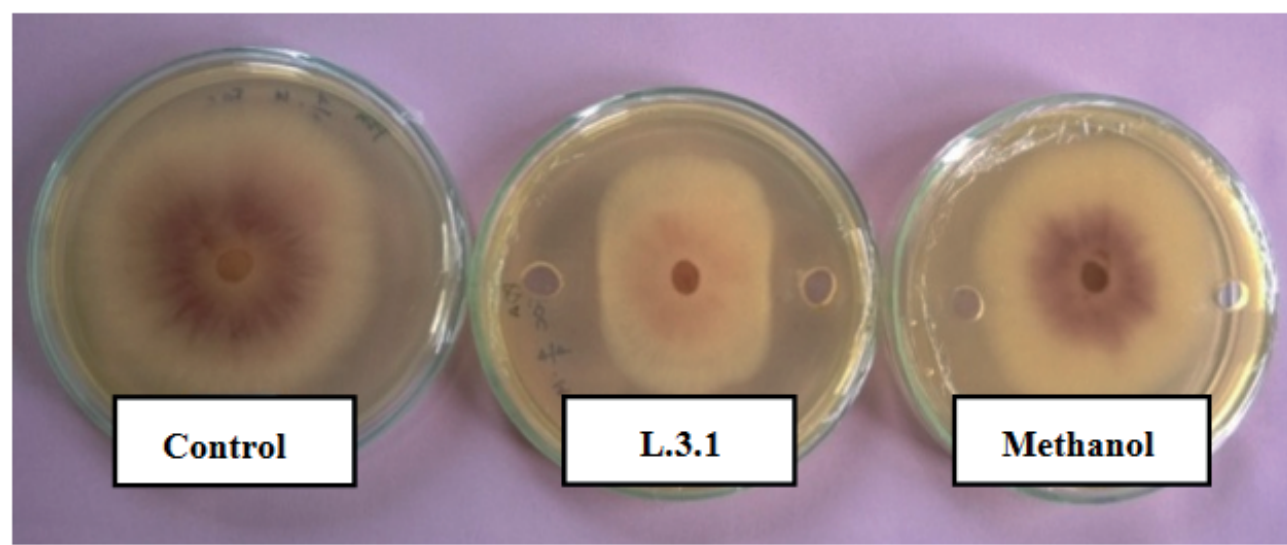

Figure 2: Antifungal activity of L.3.1 against Fusarium oxysporum f.sp. cubense (FOC).

organic material from plant roots and root exudates [3]. All isolates were screened for their ability to produce antifungal compound.

The culture filtrate of L.3.1 and CilA5b isolates were extracted with ethyl acetate : methanol $(4: 1)$ for extracting secondary metabolites that have inhibitory activity against plant pathogenic fungi, Fusarium oxysporum f. sp. cubense (FOC). Different plants species and varieties might produce different types of root exudates, which could support the activity of microorganisms for antifungal production [3, 21]. It is possible that that excretions from the roots of Musa sp. might induce Actinomycetes that show antifungal activity.

The results indicated that L.3.1 and CilA5b release an extra diffusible metabolite that inhibit hyphal growth of Fusarium oxysporum f. sp. cubense (see Figure 1). The antagonistic potential, involving the production of antifungal compounds of Actinomycetes isolated from plant rhizosphere soils to pathogenic fungi, involving the production antifungal compound has been reported [22].

Fungal cell walls often contain chitin as major component, and are suscepticable to chitinases [23]. Antagonistic activity of several streptomyces spp. against a number 


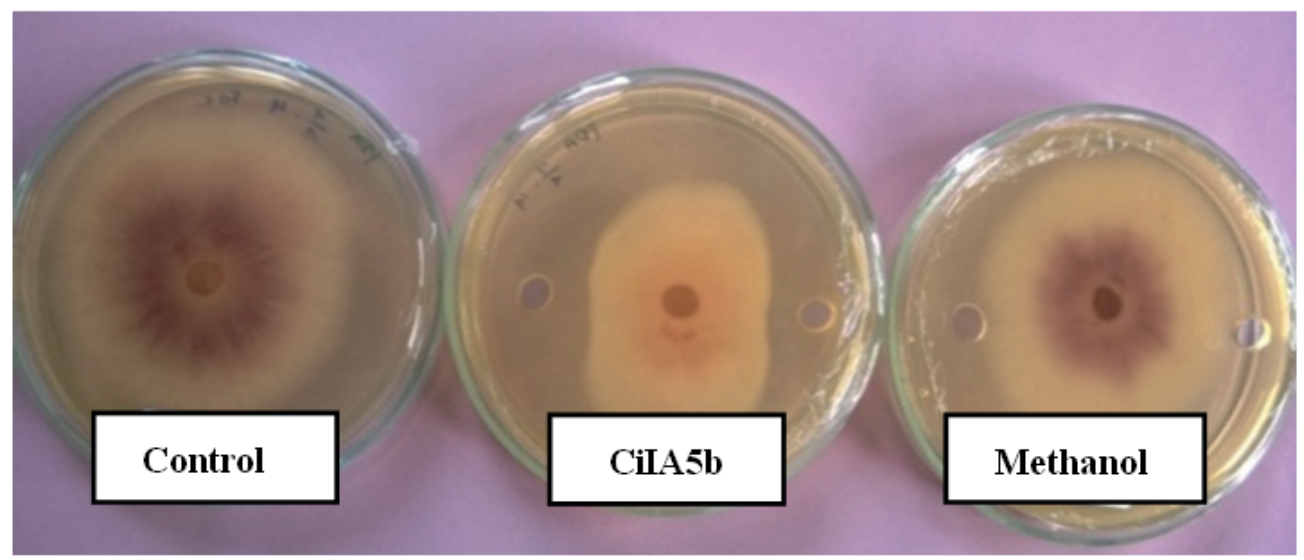

Figure 3: Antifungal activity of CilA5b against Fusarium oxysporum f.sp. cubense (FOC).
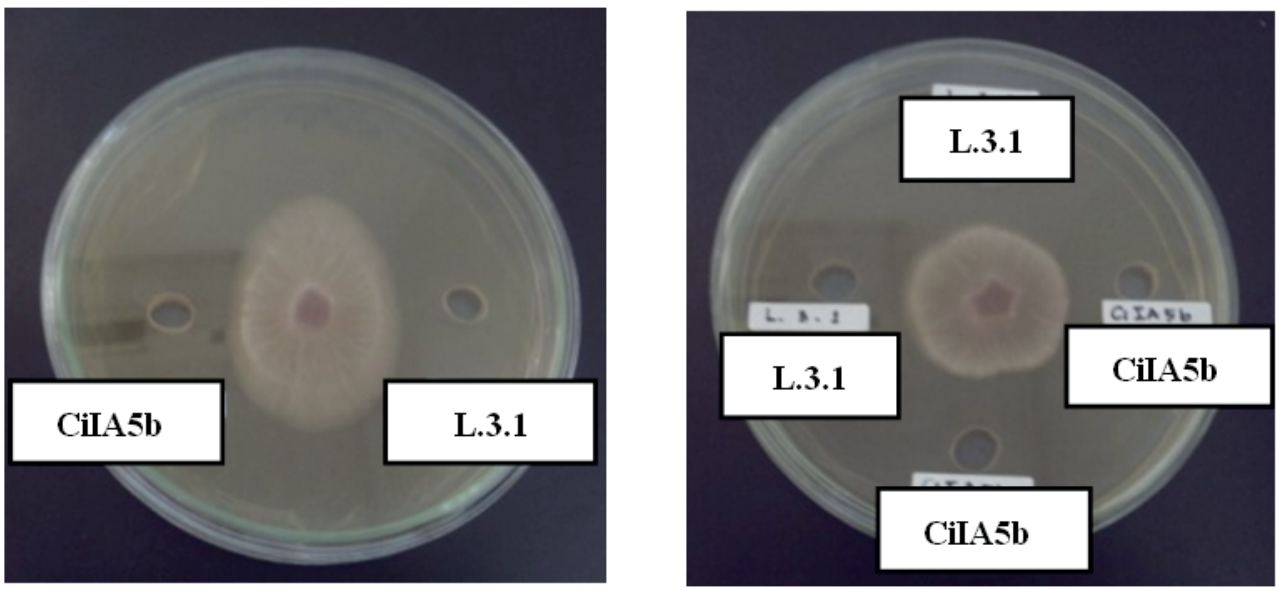

Figure 4: Antagonistic effects of metabolites of L.3.1 and CilA5b on FOC by agar well diffusion method.

of fungal pathogenic species has been known for a long time [24]. The purified chitinase lysed the mycelium and inhibited spore germination of $F$. oxysporum. In previous studies, it was noted that some microorganisms which inhibited pathogens on agar also did so in soil, whereas those ineffective on agar were also ineffective in soil [25]. L.3.1 and CilA5b were selected for biocontrol agents-the ability to produce extracellular metabolites actives against several phytopathogenic fungi, including FOC. The antagonism between Actinomycetes and the pathogen may have involved production of secondary metabolites in agar [22].

Culture of L.3.1 (see Figure 2) and CilA5b (see Figure 3) in liquid media produced extracellular metabolites that showed clear zones of inhibition against FOC. In agar well diffusion method the crude extract of L.3.1 and CilA5b showed good against Fusarium oxysporum f. sp. cubense. The crude extract has the ability to inhibit growth of FOC.

Morphology of phytopathogenic fungi (see Figure 4) was changed, the growth was very slow and the mycelium was destroyed. In their crude form, these metabolites inhibited spora germination and hyphal development of FOC, and induced morphological changes such as swollen [26].

The ethyl acetate extract of L.3.1 and CilA5b (see Figure 5) were fractionated using silica gel Thin Layer Chromatography (TLC) to identify the active metabolites with 


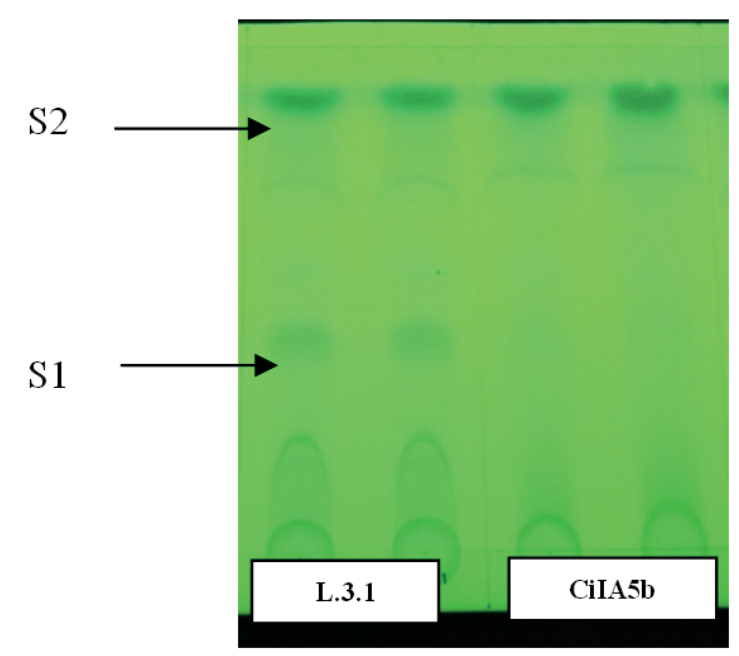

Figure 5: TLC analysis of ethyl acetate extract of L.3.1 and Ci.IA5b.

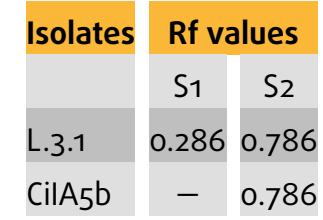

TABLE 1: Results for TLC.

antifungal activity. Each extract produced two and one spot when the chromatogram was visualized under UV lamp at $254 \mathrm{~nm}$. One spot of CilA5b has Rf values 0.786 . Two spots of L.3.1 have Rf values 0.286 and 0.786 .

Bioautography of the extract of L.3.1 and CilA5b tested against FOC (see Figure 6), confirmed the antifungal activity of specific fraction of TLC. Inhibition of FOC growth was detected as white spot indicated the presence of antifungal compound. The fraction F2 was identified to have antifungal activity against FOC, where clear white spot of inhibited area was observed in contrast to black colored growth of FOC.

Bioautography technique was very useful for detection of antifungal compound of ethyl acetate extract on thin layer chromatograms. Bioautography methods use in this study was found to be most simple, rapid and efficient method for direct tracking of antifungal fraction from the crude extract [27]. Antifungal metabolites can be readily located on the plates by visually observing cear zones where active compounds inhibit fungal growth.

\section{Conclusion}

The present study reported the activities of secondary metabolites by Actinomycetes strain against Fusarium oxysporum f.sp. cubense (FOC). This is indicated that secondary metabolites of Actinomycetes have antifungal activity. The bioautography assay show that this isolates can produces antifungal compound. Therefore, this isolates proves to be a promising isolates which can be further studied for its applications a biocontrol agent against plant pathogenic fungi. 


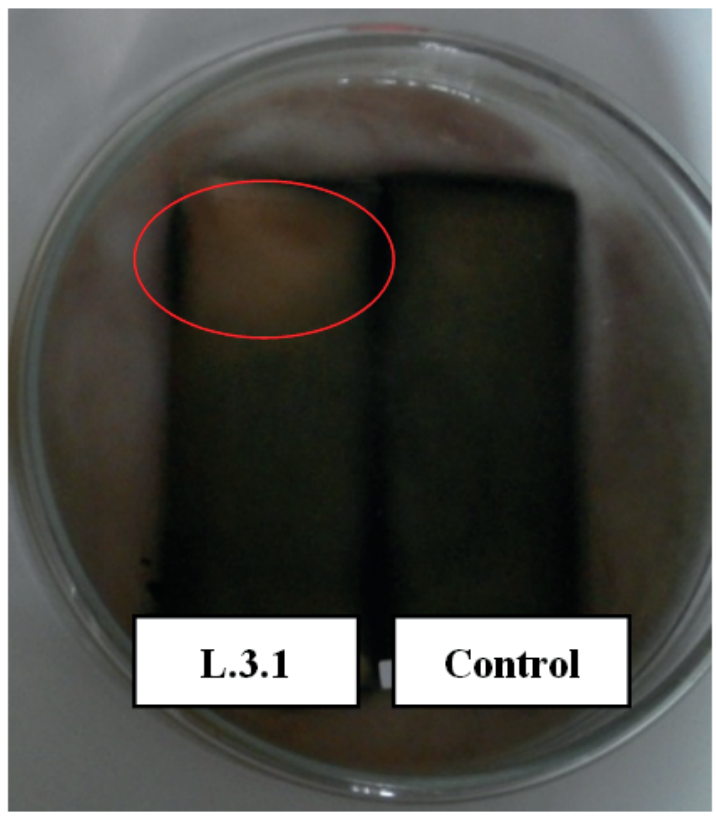

Figure 6: Bioautography of ethyl acetate extract of L.3.1 against Fusarium oxysporum f.sp. cubense (FOC).

Further investigaton is needed to optimization of this isolate's antifungal activity, purification and structure of the active compounds to scale up the production

\section{Acknowledgements}

This research was funded by DIPA Kompetitif 2014 and DIPA 2015, Research Center for Biology, Indonesian Institute of Sciences. We also thank to Entis Sutisna, Nani Mulyani and Astri Anggraeni for technical support.

\section{References}

[1] T. A. Brimner and G. J. Boland, "A review of the non-target effects of fungi used to biologically control plant diseases," Agriculture, Ecosystems and Environment, vol. 100, no. 1-3, pp. 3-16, 2003.

[2] T. Raguchander, K. Jayashree, and R. Samiyappan, "Management of Fusarium wult of banana using antagonistic microorganisms," J Biol Control, vol. 11, pp. 101-105, 1997.

[3] S. Khamna, A. Yokota, J. F. Peberdy, and S. Lumyong, "Antifungal activity of Streptomyces spp. isolated from rhizosphere of Thai medicinal plants," International Journal of Integrative Biology, vol. 6, no. 3, pp. 143-147, 2009.

[4] M. SHIMIZU, Y. NAKAGAWA, Y. SATO et al., "Studies on Endophytic Actinomycetes ( I ) Streptomyces sp. Isolated from Rhododendron and Its Antifungal Activity," Journal of General Plant Pathology, vol. 66, no. 4, Pp. 360-366, 2000.

[5] L. Yang, J. Xie, D. Jiang, Y. Fu, G. Li, and F. Lin, "Antifungal substances produced by Penicillium oxalicum strain PY-1 - Potential antibiotics against plant pathogenic 
fungi," World Journal of Microbiology and Biotechnology, vol. 24, no. 7, pp. 909-915, 2008.

[6] S. Ravikumar, S). Inbaneson, M. Uthiraselvam, Priya Sr., A. Ramu, and MB. Banerjee, "Uthiraselvam M, Priya SR, Ramu A, Banerjee MB. Diversity of endophytic actinomycetes from Karangkadu mangrove ecosystem and its antibacterial potential against bacterial pathogens," J Pharm Res, vol. 4, no. 1, pp. 294-296, 2001.

[7] V. Vimal, BM. Rajam, and K. Kannnabiran, "Antimicrobial activity of marine actinomycetes, Nocardiopsis sp. VITSVK 5 (FJ973467)," Asion J Med Scie, vol. 5, pp. 57-63, 2009.

[8] S. Ramesh, M. Rajesh, and N. Mathivanan, "Characterization of a thermostable alkaline protease produced by marine Streptomyces fungicidicus MML1614," Bioprocess and Biosystems Engineering, vol. 32, no. 6, pp. 791-800, 2009.

[9] P. R. Jensen, P. G. Williams, D.-C. Oh, L. Zeigler, and W. Fenical, "Speciesspecific secondary metabolite production in marine actinomycetes of the genus Salinispora," Applied and Environmental Microbiology, vol. 73, no. 4, pp. 1146-1152, 2007.

[10] S. Valli, S. S. Sugasini, O. S. Aysha, P. Nirmala, P. Vinoth Kumar, and A. Reena, "Antimicrobial potential of actinomycetes species isolated from marine environment," Asian Pacific Journal of Tropical Biomedicine, vol. 2, no. 6, pp. 469473, 2012.

[11] M. Goodfellow and KE. Simpson, "Ecology of Streptomyces," Front Appl Microbiol, vol. 2, pp. 97-125, 1987.

[12] J. Berdy, "Are Actinomycetes exhausted as a source of secondary metabolites?" Russion Biotechnol c/c of Biotekhnologiia, vol. 7, pp. 3-23, 1995.

[13] R. H. Baltz, "Genetic manipulation of antibiotic-producing Streptomyces," Trends in Microbiology, vol. 6, no. 2, pp. 76-83, 1998.

[14] K. A. El-Tarabily, M. H. Soliman, A. H. Nassar et al., "Biological control of Sclerotinia minor using a chitinolytic bacterium and actinomycetes," Plant Pathology, vol. 49, no. 5, Pp. 573-583, 2000.

[15] R. Errakhi, F. Bouteau, A. Lebrihi, and M. Barakate, "Evidences of biological control capacities of Streptomyces spp. against Sclerotium rolfsii responsible for dampingoff disease in sugar beet (Beta vulgaris L.)," World Journal of Microbiology and Biotechnology, vol. 23, no. 11, pp. 1503-1509, 2007.

[16] M. Goodfellow and S. T. Williams, "Ecology of actinomycetes.," Annual Review of Microbiology, vol. 37, pp. 189-216, 1983.

[17] M. J. Bibb, "Regulation of secondary metabolism in streptomycetes," Current Opinion in Microbiology, vol. 8, no. 2, pp. 208-215, 2005.

[18] D. E. Wedge and D. G. Nagle, "A new 2D-TLC bioautography method for the discovery of novel antifungal agents to control plant pathogens," Journal of Natural Products, vol. 63, no. 8, pp. 1050-1054, 2000.

[19] N. Hemashenpagam, "Purification of secondary metabolites from soil actinomycetes," Inter J of Microbiol Res, pp. 148-156, 2011. 
[20] NN. Patil, MS. Waghmode, PS. Gaikwad, MH. Gajbhai, and AV. Bankar, "Bioautography guided screening of antimicrobial compounds produced by microbispora V2," Int Res J of Biol Scie, vol. 2, no. 2, pp. 6-8, 2013.

[21] P. Lemanceau, T. Corberand, L. Gardan et al., "Effect of two plant species, flax (Linum usitatissinum L.) and Tomato (Lycopersicon esculentum Mill.), on the diversity of soilborne populations of fluorescent pseudomonads," Applied and Environmental Microbiology, vol. 61, no. 3, pp. 1004-1012, 1995.

[22] D. L. Crawford, J. M. Lynch, J. M. Whipps, and M. A. Ousley, "Isolation and characterization of actinomycete antagonists of a fungal root pathogen," Applied and Environmental Microbiology, vol. 59, no. 11, pp. 3899-3905, 1993.

[23] R. C. Gomes, L. T. A. S. Semêdo, R. M. A. Soares, C. S. Alviano, L. F. Linhares, and R. R. R. Coelho, "Chitinolytic activity of actinomycetes from a cerrado soil and their potential in biocontrol," Letters in Applied Microbiology, vol. 30, no. 2, pp. 146-150, 2000.

[24] W. M. Yuan and D. L. Crawford, "Characterization of Streptomyces lydicus WYEC108 as a potential biocontrol agent against fungal root and seed rots," Applied and Environmental Microbiology, vol. 61, no. 8, pp. 3119-3128, 1995.

[25] D. R. Fravel, "Role of Antibiosis in the Biocontrol of Plant Diseases*," Annual Review of Phytopathology, vol. 26, no. 1, pp. 75-91, 1988.

[26] K. Getha and S. Vikineswary, "Antagonistic effects of Streptomyces violaceusniger strain G10 on Fusarium oxysporum f.sp. cubense race 4: Indirect evidence for the role of antibiosis in the antagonistic process," Journal of Industrial Microbiology and Biotechnology, vol. 28, no. 6, pp. 303-310, 2002.

[27] B. K. Nagaraja, R. Sripathy, C. N. Ramchand, and M. Sundararaman, "Bioautography guided identification of anticandidal compounds from A. terreus st. 1," American Journal of Infectious Diseases, vol. 7, no. 4, pp. 91-97, 2011. 